\title{
Gen C and Gen Y: Experience, Net emotional Value and Net Promoter Score
}

\author{
Syafrizal Helmi Situmorang \\ Department of Management \\ University of Sumatera Utara, Medan, Indonesia \\ shelmi09@gmail.com
}

\begin{abstract}
We live in a world with more brands and more choice than ever before. This Study examines Generation $\mathrm{C}$ and $\mathrm{Y}$, how they feel, sense and interact with brands. Memorable experience will affect to positive emotion and brand loyalty The data for study represent 200 participant Gen C and Gen Y accros 145 brands including local, national and multinational brand. Customer experience measured against customer expectation across all moment contanct with brand. Net Emotional Value (NEV) measured by single number that represents how your customers feel net of positive emotions less negative emotions. Measuring brand loyalty based on Net Promoter Score. Findings from the research that Gen C and Gen Y have diffrent behaviour in experience, emotional and loyalty. The findings also show local brand and national brand can compete with multinational brand. The study also discusses theoretical and managerial implication of experience, emotional and brand loyalty research
\end{abstract}

Keywords: Experience, Net Emotional Value, Net Promoter Score, Brand Loyalty

\section{INTRODUCTION}

Indonesia one of the most attractive emerging markets. Since 2010, Consuming class individuals with net income above $\$ 3,000$ grows very rapidly. Many of Indonesia's low-income consumer transform to the middle income segment. This rapid increase of middle class also leads to the growth of consuming class. Rastogi et all (2013) state there are currently about 74 million people in Indonesia, and this number will increase twice in 2020. Now, many cities and regencies in Indonesia with the middle class and affluent consumer populations. Gross Domestic Product per capita in Indonesia last recited at 3834.06 dollars in 2015. Bank Indonesia estimated in 2016, Indonesia's economic growth of 5.4 percent. The World Bank predicts that Indonesia's economic will grow 5.1\% (2016) and 5.3\% (2017).

Delloite (2015) surveys to 2000 household in five major cities in Indonesia. The consumer becomes more sophisticated in their shopping behavior. Price becomes a less important consideration and consumers begin emphasis brand image. For packaged food and beverages the local taste drives consumer purchase and preference for the local brand. Recently, consumers behavior and levels of brand loyalty have changed. They like to try a different brand, willing to pay more for premium products, and willing to borrow money to finance and purchase products moreover. They also like to shop to convenience-store (modern retail). They has begun to enjoy the entertainment, travel and leisure destinations, health care, well buying, online activity and digital connection, financial planning, and out door activity. Products/services that once were only enjoyed by the upper class, now has been enjoyed by many people (Taufik, 2012. Yuswohady and Gani, 2016).

The growing number of foreign players entering the Indonesian market has given benefits for local consumers who want to get an alternative products. Local consumers trust the global brands because they are better than local brands. The entry of multinational brands create many choices to try new products / service. Consumers have become unloyal. Competition in the domestic market will further intensify. Companies or brands from Indonesia must compete to the multinational brand. How do local or national brands face the competition from larger global brands? how Indonesian brands survive? How do we do to build the consumer loyalty to their own country's products? 
Loyalty is built on trust and experience. According to Schmitt (2010), marketing practitioners have come to realize that understanding how customers experience the brand and in turn how to provide for their attractive brand experience, it is important to differentiate their offerings in a competitive marketplace. According to Fanderl et all (2016) company must listen to customers saying and connect it to the innovation. it means that to put a customer's expectation at the center of a business strategy. Their research finds that customer journeys are significantly better correlated with business outcomes.

Every generation behaves differently from other generations. Tapscott (2009) explainedthe Net Generation (Gen Y) was born 1976-1997 and Generation Next (Gen C) was born 1998-present). Delloite (2016) called people was born after 1982 is Millenial Generation. Generation C and Gen Y are searching brand that add good to the world and are commited to making our planet a better place. They put confidence in businesses have a positive impact on wider community. They will chose brands to assistthem make their societies better and provide them with the tool they need to impact their word. Millenial expects brands to not just speak to them but actually listen to them. They don't want to just buy a brand; they want to be a part of it. They're looking for ways to participate (Fromm and Garton, 2013).

There are several researches have discussed the customer experience, emotional value and net promoter score. however, there is only limited research which compare those variable on local, national and multinasional brands in indonesia for Gen C and Gen Y. This paper measured53 brands experience, emotional and loyalty in Gen Y and 92 experience, emotional and loyalty brands in Gen C. This paper also tried to measure competition between national and multinational brands in Gen $\mathrm{Y}$ and competition between local, national and multinational brands in Gen C. The finding showed that In Gen Y, global brand higher than national brands but in Gen $\mathrm{C}$ local brands can compete with national and multinational brands. It means local brands have ready aware that important to understanding and fulfilling desire and anxiety customers.

\section{RESEARCH METHODS}

Research design is the methodology and procedures to conduct research. The design of the study defines the research question, data collection method and decriptive statistical analysis plan. The design for this research work is quantitative method. The population for this study is defined as Gen Y and Gen C with sample size 200 respondent. Survey was conducted from April-September 2016, In mayor city Medan, Indonesia There are 92 brand (18 categories) for Gen C and 53 brands (15 categories) for Gen Y.

A questionnaire was developed and administered on-site to respondents by trained interviewers to collect data. Questionnaires were included the following main topics : ( 1 ) Customer Experience (2) Emotional Value (3) brand Loyalty. Each variable in the model was measured using a multi-attribute instrument adapted from previous studies in order to enhance content validity in the operationalization.

Customer experience in this research measured by customer expectation about a moment of truth with a simple question such as how much better was your experience with brand compared to what you expected? (on a scale of 110). Customer experience in this Questionnaire embrace of social environment, human element, service interface, store atmosphere, assortment, advertising, price, product \& service Features and ease of use. Each category of brands have different measurement.

Emotional Value is measured by Emotional Signature,develoved by Shaw (2007). Shaw measured Net Emotional Value (NEV)as a single number that represents how your customers feel towards you. NEV is the net of positive emotions less negative emotions. shaw divided emotional value into two parts. The First, part is value destroyers (negative emotions) for instance irritated, stressed, negleted, unsatisfied, frustated, dissapointed, unhappy, and hurried. Secondly, part is value driver (positive emotions) like stimulated, interested, explatory, energetic, indulgent,valued, cared for, trusted, focused, safe,pleased, and happy.

While Brand loyalty is measured by Net Promoter Score (NPS). NPS is a metric for measuring customer loyalty based on one single question such as What is the likelihood that you would recommend (our company) to a colleague or friend? (on a scale of 1-10). The Zero (0) means 
not likely at all and ten (10) means very likely. NPS is determined by subtracting the percentage of customers who are detractors from the percentage who are promoters. Customers can be categorized based on their answer to the ultimate question (Reichheld and Markey, 2011).

Regards to the quantitative approach, after the collection of all the questionnaires the data was edited and given codes to facilitate the transfer to the computer software (SPSS). The researcher used tables to explore the patterns of the data. From 150 brand, researcher eliminating 5 brandbecause excessive missing data or contradictory answers.

\section{RESULTS AND DISCUSSION}

\section{Customer Experience}

Lasalle and Britton (2002) define experience as "an interaction, or series of interactions, between a customer and a product, a company or its representative that lead to a reaction. Customer experience is from starbuck case, whereas people come to look for comfortable situation and they are valued on a personal level, and meaningful relation is made. To achieve this, the store atmosphere must be a place where a person will feel comfortable hanging out alone or with friends (Michelli, 2007). Experience comes from the heart, feeling and emotions of customers which they cannot easily express, hence it makes almost impossible for companies to satisfy every customer (Zang, 2010).

From Table 1. It can be seen mean, median, and mode of Customer Experience (CX) of Gen C higher than Gen Y. It means the moment of truth which is experienced by Gen $\mathrm{C}$ on the brands has met their expectation. For instance, the experience on store atmosphere, price and advertising has demonstrated the brands ability in fulfilling desire and anxiety customers. According to Gupta and Vajic (2000), Experiences happen when customers interact with one elements of the brand context and, as a result, extract sensations, emotions, or cognitions that will connect them to the brand in a personal and memorable way.

In Gen $\mathrm{C}$ the brand Star of customer experience (CX) are Line (messenger), Gogo (food) and Bolt (Internet data). There are 50 brands from 93 brands (54,35\%) have above an average of CX. In Gen Y the brand Star of customer experience are Gojek (domectic courier) , Liputan 6 (media online) and BNI (banking). There are 28 brands form 53 brands $(52,83 \%)$ above an average of CX.

Arussy (2004) pointed out that Experience must constantly improve. The company must deliver a new exciting experience every day. Rediscovering relationships and rejuvenating customer experience make them excited and keep them coming back for more. Study by Temkin research (2012) examined the correlation between the customer experiences delivered and customers loyalty. This research shows that good customer experience correlates to consumers' willingness to repurchase, reluctance to switch, and likelihood to recommend. It also supported by Lhuer et all (2015) state in order to create distinctive customer journeys, companies have to understand their customers' behavior, build connection and deep empathy when they experienced difficulties and obstacles. A Truly understanding customer needs may help the companies not only improve the buying experience but also their bottom line.

Table 1. Descriptive Statistic Customer Experience

\begin{tabular}{|c|c|c|}
\hline & Gen C & Gen Y \\
\hline $\mathrm{N}$ (Brand) & 92 & 53 \\
\hline Mean & 80,1 & 77,4 \\
\hline Median & 81,3 & 77,4 \\
\hline Mode & 81,7 & 80,0 \\
\hline Minimum & 62,9 & 69,2 \\
\hline Maximum & 87,9 & 89,1 \\
\hline
\end{tabular}

\section{Net Emotional Value}

Experiences such as sense, feel, think, act, and relate will engage customers to create memorable events and connect them emotionally to the company or the brand (Pine and Gil more, 1998, Schmitt 1999). Without experience and emotional value, customer will lack of the drive, motivation, and triggers decision and purchase. Its important to companies to know how they can connect with emotional customer (Surdak and King, 2015).

The table 2 shows the average value of Net Emotional Value (NEV) of Gen C higher than Gen Y. It means Gen $\mathrm{C}$ has more positive feelings on brands such as interested, valued, cared for, 
trusted, , safe,pleased, and happy than negative feelings. The Brand star of Net emotional value of Gen C are Safari (browser), CNN Indonesia (Online News), Deal Medan (e-commerce). All respondents have positive emotion about the brand. There are 66 brands from 93 (72\%) above the average of NEV. The Brandsstar of Net emotional Value of Gen Y are Gojek, Tiki and Traveloka. There are 54,71\% of total which have NEV above avarage.

Customers expect emotional value of brand that complement their lifestyle, and aspirations. In this way, brand must develop emotional connections and relationships with consumers. It will bring brands deliver the promise in a way which brings the brand alive in customers (Smith and Wheeler ,2002)

Table 2 . Descriptive Statistic Net emotional

\begin{tabular}{|l|c|l|}
\hline \multicolumn{1}{|l}{ Value } \\
\hline & \multicolumn{1}{|l|}{ Gen C } & Gen Y \\
\hline N (Brand) & 92 & 53 \\
\hline Mean & 76,91 & 70,26 \\
\hline Median & 83,00 & 73,26 \\
\hline Mode & 84,00 & 77,14 \\
\hline Minimum & $-22,00$ & 33,33 \\
\hline Maximum & 100,00 & 89,29 \\
\hline
\end{tabular}

\section{Brand Loyalty and Net Promoter Score}

Loyalty is the willingness of customers to recommend the brand that they used, investing and personal sacrifices in order to strengthen its relationship with the brand. Oliver (1999) defined customer loyalty as a deeply held commitment to rebuy or repatronize a preferred product or service consistently in the future, causing repetitive same brand or same brand-set purchasing, despite situational influences and marketing efforts. Brand loyalty is based on an authentic connection the consumer makes with a company's products or services. Determining your brand's position is key to create and maintain the brand loyalty in order to make it closer to their customers.

Table 3 exhibits the avarage value of Net Promoter Score (NPS) of Gen C higher than Gen Y. It may indicate customer in the Gen $\mathrm{C}$ have higher willingness to pay, come back more often, buy additional products and services, refer their friends. The Brand Star NPS of Gen C are Deal Medan, Instagram and Line. There are 62 brands
(67\%) above average of NPS. Brand star of NPS Gen Y are Gojek, iPhone and BCA. There are 23 brands $(43,4 \%)$ above average of NPS.

Reicheld (1996) pointed out loyalty behaviour affect business growth and companies get profit from price premium, referrals, increase purchases and higher balances, reduced operating cost and customer acquisition cost. True loyalty clearly affects profitability. Studies in a number of industries have revealed that the cost of keeping existing customers is about 10\% of the cost of of acquiring a new one.

Table 3 . Descriptive Statistic Net Promoter Score

\begin{tabular}{|l|r|l|}
\hline & \multicolumn{1}{|l|}{ Gen C } & Gen Y \\
\hline N (Brand) & 92 & 53 \\
\hline Mean & 36,16 & 33,36 \\
\hline Median & 42,50 & 31,00 \\
\hline Mode & 38,00 & 26,00 \\
\hline Minimum & $-64,00$ & 5,00 \\
\hline Maximum & 89,00 & 78,00 \\
\hline
\end{tabular}

The majority of brands star in Gen Y are brands which have strong correlation with the lifestyle or daily life activity such as banks, online news, goods delivery (courier). Meanwhile, the brands star for Gen C are internet or social media brands related. Based on result gen $\mathrm{C}$ have higher experience, positive emotional feeling on brand, and recommend brands to their friends than Gen Y. As a matter of fact Gen $C$ is a powerful new force in consumer culture. It is a term we use to describe people who care deeply about creation, curation, connection, and community (Google, 2013). It also supported by Friedrich et all, (2010) were Gen C stands for connecting, computerized, communicate, and change. They born after 1990, who are highly connected generation. Its unlike other age groups, Gen C connected personally with other people, like new content, try the new devices and new experiences the (Nielsen, 2012).

\section{Comparison CX, NEV and NPS between National and Multinational Brand in Gen $Y$}

Table 4 shows the value NPS, CX dan NEV Multinational brands higher than National brands. National brands must improve brand awareness, increase communication, and interaction moment of truth to customers. Shaw, 
(2005) suggest customer experience is about human interaction. Recognize that your customers. being able to relate to customers experiences is a key to deliver the best experiences.

Table 4 . Comparison CX, NEV and NPS Gen

\begin{tabular}{|l|l|l|l|l|}
\hline \multicolumn{5}{|c}{ CY } \\
\hline \multirow{2}{*}{$\begin{array}{l}\text { Gen } \\
\text { Y }\end{array}$} & $\begin{array}{l}\text { National } \\
\text { Brands }\end{array}$ & 31,69 & 7,55 & 71,5 \\
\cline { 2 - 5 } & $\begin{array}{l}\text { Multinational } \\
\text { Brands }\end{array}$ & 34,23 & 7,66 & 65,67 \\
\hline
\end{tabular}

Frei and Moris, (2012) recommended a diagnostic phase when companies create their own atribute services. Analyze company performance and compare to competitor, and then react (physical behaviors, lifestyles, and interactions) and redefine value through creating sensory experiences (sight, sound, touch, taste and smell). This process will help not only the happiness of customer but also how well company performance is aligned with preferences.

\section{Comparison CX, NEV and NPS between Local, National and Multinational Brand in Gen C}

The personal value variations of both Gen $Y$ and gen $\mathrm{C}$ will affect the shopping behavior. Gne $\mathrm{Y}$ and Gen $\mathrm{C}$ have differentpersonal value. From the table 5, it can be illustrated that value NPS, CX dan NEV a local brands are higher than national and Multinational brands. It means the local brands able to fulfill the expextation of Gen C.

Table 5. Comparison betwen Local, National and Global Brand in Gen $\mathrm{C}$ and Gen Y

\begin{tabular}{|l|l|l|l|l|}
\hline & & NPS & CX & NEV \\
\hline \multirow{4}{*}{ Gen C } & $\begin{array}{l}\text { National } \\
\text { Brand }\end{array}$ & 23,59 & 7.60 & 68.29 \\
\cline { 2 - 5 } & Global Brand & 39,19 & 8,14 & 82,48 \\
\cline { 2 - 5 } & Local Brand & 54,08 & 8,24 & 84,19 \\
\hline
\end{tabular}

Shaw and ivans, (2002) suggest that consumers are always looking for an experience that allows them to realize their dreams and achieve their desired life style. Companies must understand what customers want, treated as an individual, care about, doing everything they could to help and make the customer as most important person in the world.Customers want to experience and they will pay for the experience (Schmitt, 2010)

\section{CONCLUSION}

The avarage of Gen $C$ have higher the moment of truth and deeper brand experience than Gen Y. The avarage of Gen C have more positive feelings such as valued, cared for, trusted, focused, safe, pleased and happy than Gen Y. Gen C have more loyalty and willingness to recommend brand to their family or friend than Gen Y. In Gen Y, Net Promoter Score, Customer Experience and Net Emotional Value of multinational brands are higher than multinational brands.In Gen C, Net Promoter Score, Customer Experience and Net Emotional Value of local brands are higher than national and multinational brands.

Customer experience is a key to win competititon and act as the differentiation value of other brands. Brands Experience contain AHA or WOW moment more likely create positive emotional value to customer. Hence, customer will be more loyal, willing to repurchase and recommend those brand to their friends or family. Therefore companies must continously improve of any aspect (physically and emotionally) in customer interaction.In order to face the challenging from international brands, national brands have to be able to design the marketing communication and activity which enable companies to provide memorable experience. This strategy will lead to the increasing of brand loyalty on customer. Moreover, national brands must able to create differentiation value based on their core competencies to achive the competitive advantage.

Local brands should be able to grow and cultivate the local value as the identity which is part of nationalism. This strategy is establishied by appling in various activities in local community. The limitation of this study is the small number of samples. In addition to that local brands should be included in Gen $\mathrm{Y}$ brand analysis. Lastly, in order to have better understanding on the relation of experience, emotional value and loyalty need to add a deeper 
statistical analysis such as regression and path analysis.

\section{REFERENCES}

Arussy, L. (2004). The Experience! How to Wow Your Customers and Create a Passionate Workplace, CMP Books, California, USA

Deloitte. (2015). Deloitte Consumer Insight: Capturing Indonesia's latent markets, Retrieved from https://www2.deloitte.com

Deloitte. (2016). Millennial Survey Winning over the next generation of leaders, Retrieved from https://www2.deloitte.com

Frei, F and Morris, A. (2012). Uncommon Service: How to win by putting customers at the core of your business, Harvard Business School Publishing, Boston

Fanderl, H., Kevin,N., and Alfonso,P. (2016). Are you really listening to what your customers are saying?, McKinsey \& Company, USA,

Friedrich, R., Peterson. M., Koster, A., and Blum, S. (2010). The Rise of Generation C \& Implications for the world of 2020, Report Booz \& Company, Retrieved from http://www.strategyand.pwc.com

Fromm, J. and Garton,C. (2013). Marketing to Millennials: Reach the Largest and Most Influential Generation of Consumers Ever, AMACOM, New York

Google. (2013). Introducing Gen C : The YouTube Generation, Retrieved from

https://www.thinkwithgoogle.com

Gupta, S. and Vajic, M. (2000). "The Contextual and Dialectical Nature of Experiences," in New Service Development-Creating Memorable Experiences, ed. James A. Fitzsimmons and Mona J. Fitzsimmons, Thousand Oaks: Sage,pp 33-51.

Lasalle, D. and Britton, T.A. (2002). Priceless: Turning Ordinary Products into Extraordinary Experiences. Harvard Business School Press, Boston, USA

Lhuer, X., Tunde, O., and Hyo, Y. (2015). What it takes to deliver breakthrough customer experiences, McKinsey Digital, Retrieved from http://www.mckinsey.com

Michelli, J.A. (2007). Starbuck experience, McGraw-Hill Companies, Inc, USA.

Nielsen. (2012). Introducing Generation C Americans 18-34 Are The Most Connected, Retrieved from http://www.nielsen.com
Oliver, R.L. (1999). Whence consumer loyalty?, Journal of Marketing, Vol. 63, pp. 33-44.

Pine II,B.J. and Gilmore, J.H. (1998). Welcome to the experential economy, Harvard Business Review, July/August, pp 97-105

Rastogi, V., Tamboto,E., Tong,D., \& Sinburimsit. (2013). Asia's Next Big Oppurtunity : Indonesia's Rising Middle-class and Affluent Consumer, The BCG Report, Boston, Retrieved from https://www.bcgperspectives.com

Reichheld, F. (1996). The Loyalty Effect: The Hidden Force Behind Growth, Profits and Lasting Value, Harvard Business School Press. Boston.

Reichheld, F and Markey, R. (2011).The Ultimate Question 2.0, How Net Promoter Companies Thrive In a Customer-Driven World, Harvard Business Review Press, Boston.

Shaw, C. and Ivan J. (2002). Building Great Customer Experience, Palgrave Macmillan, New York

Shaw, C. (2005). Revolutionize Your Customer Experience, Palgrave Macmillan, New York

Shaw, C. (2007). DNA of The DNA of Customer Experience How Emotions Drive Value, Palgrave Macmillan, New York

Schmitt, B.H. (1999). Experiential Marketing, Free Press, New York

Schmitt, B.H. (2010). Experience Marketing: Concepts, Frameworks and Consumer Insights, Foundations and Trends in Marketing Vol. 5(2),pp55-112,

Schmitt, B.H. (2010). Experience Marketing: Concepts, Frameworks and Consumer Insights, Foundations and Trends in Marketing Vol. 5, (2)pp55-112.

Smith, S and Weller J. (2002). Managing the customer experience : Turning customers into advocates, Pearson Education Limited, London

Surdak, C., and King E.D. (2015). Selling Illusory Joy :Emotion, Big data and Coming Retail Renaissance, Europian Business Review May-Juni, pp 33-37

Tapscott, D. (2009). Grown Up Digital, How the Net Generation Is changing Your World, McGraw Hill, New York

Taufik. (2012). Raising Middle Class In Indonesia, Gramedia Pustaka , Jakarta

Temkin, B. (2012). The ROI of Customer Experience : Analysis show high Correlation between Customer experience 
and Loyalty, Retrieved from http://www.oracle.com

Yuswohady and Kemal E.G. (2016). 8 Wajah Kelas Menengah, Gramedia Pustaka, Jakarta

Zhang, J. (2010). The Coming Era of Experience Economy and Breakthrough of Service Innovation Dilemma, Management and Service Science, IEEE Explore Conferences, pp.1-4, 